\title{
35. TRACE ELEMENT GEOCHEMISTRY OF IGNEOUS ROCKS FROM SITE 334, LEG 37
}

\author{
J. Dostal and G.K. Muecke, Department of Geology, Dalhousie University, Halifax, Nova Scotia, Canada
}

\begin{abstract}
Rare earth elements (REE)-Sc, $\mathrm{Co}, \mathrm{Cr}, \mathrm{Hf}$, and $\mathrm{Th}$-were determined in basalts, gabbros, and peridotites from Site 334 by neutron activation analysis. The basalts show generally flat REE patterns with slight light REE depletion or enrichment. Total REE content and $\mathrm{FeO}_{\text {tot }} / \mathrm{MgO}$ ratios increase progressively from the base to the top of the basalt sequence and are thought to reflect the evolution of the basalts from a similar parent magma body undergoing shallow fractional crystallization.

The gabbros show considerably lower total REE content and more fractionated patterns. A gradual and systematic depletion of the light relative to the heavy REE produces sloping patterns, and Eu shows distinct positive anomalies. The REE data are consistent with the derivation of the gabbros as crystal cumulates from a basaltic liquid.

Peridotite REE patterns resemble those of the gabbros and total REE abundances of these two groups overlap. This similarity suggests that they may be derived as cumulates from the same or similar parental magmas. The absence of distinctive Eu anomalies in the overlying basalts makes it unlikely that the basalts represent the residual liquid from which the gabbroic and peridotitic cumulates separated.
\end{abstract}

\section{INTRODUCTION}

Ultramafic and gabbroic rocks from the ocean floor are of considerable interest since many lines of evidence indicate that they may be the key to explaining the petrology of mid-ocean ridges (e.g., Thayer, 1969) and may also provide some constraints on the chemistry of the suboceanic upper mantle or lower crust. Thus the basalt-gabbro-peridotite sequence encountered at Site 334 provides an opportunity to evaluate the subsurface igneous processes beneath the mid-ocean ridge system and possibly to determine the nature of the original magmas. The major purpose of this study is to report the abundances of rare-earth elements (REE)-Sc, $\mathrm{Cr}, \mathrm{Co}, \mathrm{Hf}$, and $\mathrm{Th}-$ in some samples of the basalt-gabbro-peridotite section of Site 334 and to briefly discuss the genetic implications of these data.

\section{ANALYTICAL METHODS}

The content of Sc, Co, Cr, Hf, and Th in all samples and that of REE in basalts was determined by instrumental activation analyses using W-1 as a standard (Gordon et al., 1968). Based upon duplicate analyses, the precision is better than $5 \%$ for $\mathrm{Sc}$, Co, and $\mathrm{Cr}$; about $30 \%$ for Hf; $50 \%$ for Th; better than $10 \%$ for REE. In the determination of REE in gabbros and peridotites, a radiochemical neutron activation technique adapted from that of Denechaud et al. (1970) was used. The procedure involves postirradiation chemical group separation of REE and their radioassay by $\gamma$-ray spectrometry using a high resolution $\mathrm{Ge}(\mathrm{Li})$ detector. The analytical precision is better than $10 \%$ for $\mathrm{La}, \mathrm{Sm}, \mathrm{Eu}$, $\mathrm{Tb}, \mathrm{Yb}$, and $\mathrm{Lu}$ and better than $25 \%$ for $\mathrm{Ce}, \mathrm{Nd}$, and Gd. Replicate analysis of standard rock W-1 indicates that the accuracy is comparable to the precision. Data are presented in Table 3 (Chapter 4 , this volume).

\section{BASALTS}

On shipboard the tholeiitic basalts of Site 334 were divided into an upper phyric and a lower aphyric lithologic unit. One of the analyzed basalts (334-15-2, $30-32 \mathrm{~cm}$ ) comes from the upper phyric unit, which in general has lower $\mathrm{Mg}$ and higher $\mathrm{Ti}$ content and $\mathrm{FeO}_{\text {tot }} / \mathrm{MgO}$ ratio, while four others represent the lower aphyric unit. The REE data for basalts are conventionally normalized to the average chondrites (Hubbard and Gast, 1971) in Figure 1a.

The total REE abundances of all analyzed basalts fall well within the range of typical oceanic tholeiites (e.g., Frey et al., 1968; Corliss, 1970; Kay et al., 1970; Schilling, 1971). All samples have a flat pattern for heavy REE, but show some variability in light REE. Sample 334-20-2, 140-145 cm has a light REE-depleted pattern similar to that commonly found along other "normal ocean ridge" segments, although the depletion is less pronounced. All other basalts show a small but noticeable light REE enrichment. Such minor light REE is similar but less pronounced than that found in MAR basalts at $45^{\circ} \mathrm{N}$ (Frey et al., 1968; Nicholls and 


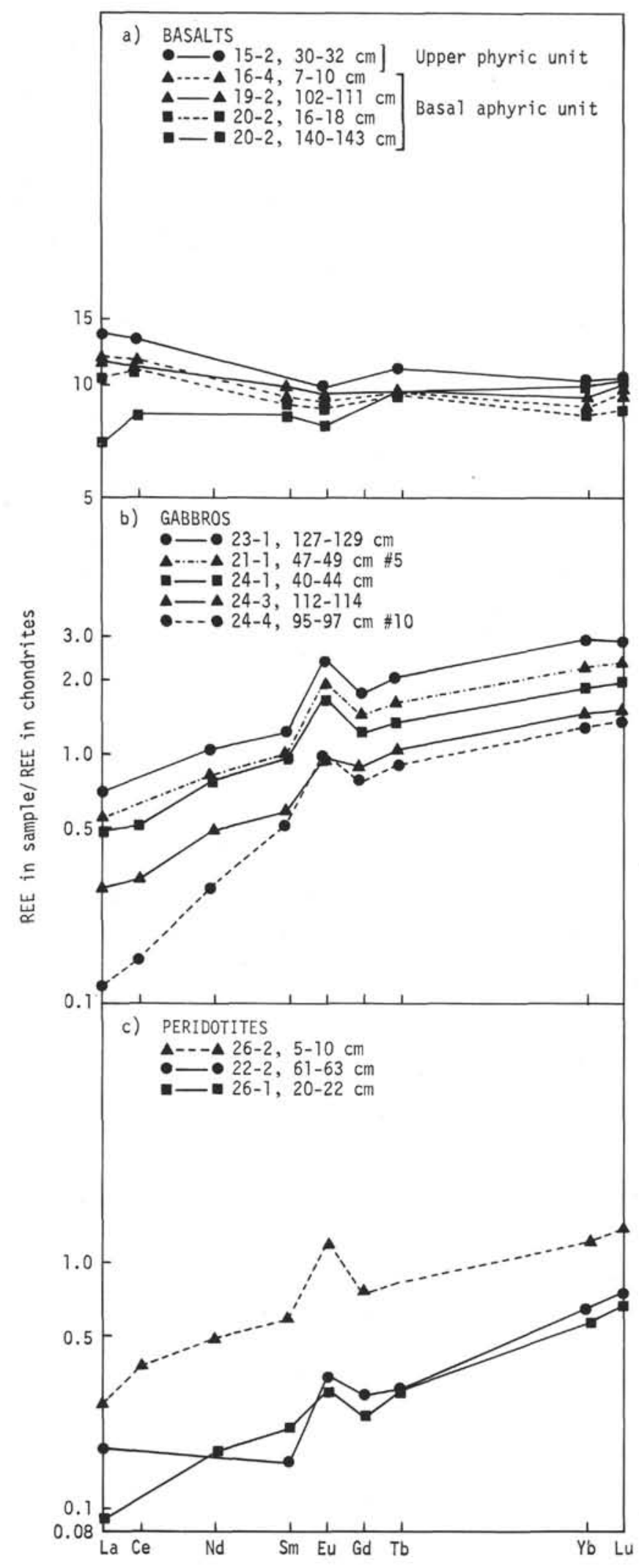

Figure 1. Chondrite-normalized REE distribution patterns of basalts, gabbros, and peridotites from Site 334, Leg 37.
Islam, 197i) or Leg 2 (Frey et al., 1974). Differences in REE abundances and patterns are reflected in other chemical parameters. The light REE-enriched basalts have distinctly lower $\mathrm{Cr}$ and higher $\mathrm{Ti}$ and total REE than basalt $(334-20-2,140-145 \mathrm{~cm})$, and within this group total REE content increases with increasing $\mathrm{FeO}_{\text {tot }} / \mathrm{MgO}$ ratio.

As far as the REE are concerned, the light REEenriched basalts can be derived from typical large ion lithophile element (LIL)-depleted tholeiite or from basalt $(334-20-2,140-145 \mathrm{~cm})$ by fractional crystallization mainly of clinopyroxene. Although basalt (334$20-2,140-145 \mathrm{~cm}$ ) is relatively unfractionated, it still is more evolved than the basalts which were suggested by Frey et al. (1974) to represent undifferentiated oceanic magma generated by partial melting of mantle peridotite. The increase of total REE content with $\mathrm{FeO}_{\text {tot }} / \mathrm{MgO}$ with little change in REE fractionation pattern can be attributed to shallow magmatic differentiation of minerals low in REE (mainly olivine) which enriches the residual magma in total REE (Kay et al., 1970; Schnetzler and Philpotts, 1968, 1970).

The total REE content, as exemplified by La abundances, increases gradually with stratigraphic position of the basalts from bottom to top of the sequence. This evolutionary trend suggests that the entire sequence could have been derived from the same or a similar parent magma body which underwent progressive shallow fractional crystallization.

\section{GABBROS}

The chondrite-normalized REE patterns of gabbros (Figure 1b) show gradual depletion from heavy to light REE with distinct positive Eu anomalies. These patterns are similar to those of other oceanic gabbros (Kay et al., 1970; Masuda et al., 1971; Shih, 1972), of gabbros from ophiolitic complexes (Montigny et al., 1973) and also of gabbros from some layered intrusions (e.g., Stillwater and Bushveld-Frey et al., 1968). This similarity together with the small differences in the relative REE fractionation among analyzed gabbros also indicates that the REE in these rocks probably retained their original patterns although some samples display a varying degree of alteration and shearing.

In comparison with associated basalts, REE of analyzed gabbros are more fractionated and are significantly lower in total concentrations. The contents of REE in gabbros appear to increase with the increase of the $\mathrm{FeO}_{\text {tot }} / \mathrm{MgO}$ ratios of the rocks, i.e., from olivine-rich gabbros to olivine-free ones, while there is little change in relative fractionation. A differentiation trend similar to that of oceanic gabbros of REE enrichment without distinct fractionation was reported for layered complexes such as Skaergaard (Haskin and Haskin, 1968; Haskin et al., 1971). This seems to suggest that the differentiation processes in both cases were similar despite the fact that the composition of the original magma was probably different as indicated by significant differences in REE fractionation patterns between oceanic gabbros and those of the Skaergaard intrusion. 
The slope of the REE patterns of analyzed gabbros probably reflects the fractionation of REE between cumulus pyroxenes and basaltic liquid, whereas the Eu enrichment is due to the accumulation of plagioclase (cf. Schnetzler and Philpotts, 1968, 1970; Shih, 1972). Since gabbros with low $\mathrm{FeO}_{\text {tot }} / \mathrm{MgO}$ ratios have higher $\mathrm{Mg}$ and $\mathrm{Cr}$ and lower $\mathrm{Al}, \mathrm{Ca}$, and $\mathrm{Na}$ contents than gabbros with high ratios, it appears that the rocks with low REE contents have a higher amount of olivine, orthopyroxene, and spinel. This indicates that the REE variation in gabbros reflects the variation in the proportions of individual mineral phases.

The trace element data are consistent with the derivation of the gabbros as crystal cumulates from a basaltic liquid similar to the ocean floor basalts which have higher $\mathrm{FeO}_{\text {tot }} / \mathrm{MgO}$ ratios and higher and less fractionated REE abundances than analyzed gabbros. The low content of REE in gabbros also suggests that the residual liquid was effectively expelled from these rocks.

\section{PERIDOTITES}

Three partially serpentinized peridotites were analyzed for REE and their chondrite-normalized patterns are shown in Figure 1c. Two peridotite samples (334-26-1, $20-22 \mathrm{~cm}$ and $334-26-2,5-10 \mathrm{~cm}$ ) have well-fractionated REE patterns similar to those of gabbros, i.e., displaying gradual depletion from $\mathrm{Lu}$ to $\mathrm{La}$ with distinct positive Eu anomalies. Concentration levels of Sample $334-26-2,5-10 \mathrm{~cm}$ are comparable to those of the olivine-rich gabbros. The third sample (334-22-2, 61-63 $\mathrm{cm})$ has a U-shaped pattern once again with the distinct Eu anomaly.

None of these patterns appears to represent an undifferentiated upper-mantle material. Significant $\mathrm{Eu}$ anomalies in these peridotites reveal that plagioclase accumulation played an important role in their evolution. Assuming that serpentinization does not significantly affect the REE distribution, the REE patterns of peridotites are consistent with their derivation as accumulates of early crystallized minerals (olivine, pyroxenes, plagioclase) from basic magma probably similar to the ocean-floor basalts. The differences in total and relative REE abundances among analyzed peridotites would mainly reflect variations in the proportions of individual mineral accumulates.

\section{CONCLUSIONS}

With respect to the petrogenesis of the coarsegrained rocks of Site 334, the important problem is the relation between peridotites, gabbros, and basalts. Since the olivine-rich gabbros and peridotites have not only about the same $\mathrm{FeO}_{\text {tot }} / \mathrm{MgO}$ ratio but also overlap in REE abundances, olivine-rich gabbros could not represent the magma from which olivine accumulated to form the peridotite. However, the similarity of the REE abundances in peridotites and olivine-rich gabbros suggests that gabbros and peridotites of Site 334 are genetically related and both could have been derived from the same or similar parental basic magma although probably not by a single continuous magmatic differentiation, as also suggested by the stratigraphic sequence. The alternation of ultramafic and mafic plutonic rocks of Site 334 is reminiscent of a rhythmically layered series.

Thus our data suggest that coarse-grained rocks at Site 334 , such as analyzed gabbros and peridotites, are accumulates produced by various stages of differentiation of basaltic liquid in a quiet environment and might represent part of a layered oceanic complex. Fractional crystallization can also account for the evolutionary sequence observed in the overlying basalts. However, the absence of distinct negative Eu anomalies in basalts of Site 334 complementary to those of gabbros and peridotites indicates that basalts at Site 334 do not represent the residual liquid from which gabbros and peridotites were already separated.

\section{ACKNOWLEDGMENTS}

We thank Dr. F. A. Frey for providing us with standard REE solutions and Dr. J. H. Crockett for the use of radiochemical separation facilities.

We are grateful to Dr. F. Aumento for critical comments on the manuscript.

\section{REFERENCES}

Corliss, J.B., 1970. Mid-ocean ridge basalts: Ph.D. Thesis. University of California at San Diego, La Jolla, California.

Denechaud, E.B., Helmke, P.A., and Haskin, L.A., 1970. Analysis for the rare-earth elements by neutron activation and $\mathrm{Ge}$ (Li) spectrometry: J. Radioanal. Chem., v. 6, p. $97-113$.

Frey, F.A., Haskin, M.A., Poetz, J.A., and Haskin, L.A., 1968. Rare-earth abundances in some basic rocks: J. Geophys. Res., v. 73, p. 6086-6098.

Frey, F.A., Bryan, W.B., and Thompson, G., 1974. Atlantic ocean floor: geochemistry and petrology of basalts from Legs 2 and 3 of the Deep-Sea Drilling Project: J. Geophys. Res., v. 79, p. 5507-5527.

Gordon, G.E., Randle, K., Goles, G.G., Corliss, J.B., Beeson, M.H., and Oxley, S.S., 1968. Instrumental activation analysis of standard rocks with high resolution $\gamma$-ray detectors: Geochim. Cosmochim. Acta, v. 32, p. 369-396.

Haskin, L.A. and Haskin, M.A., 1968. Rare-earth elements in the Skaergaard intrusion: Geochim. Cosmochim. Acta, v. 32 , p. $433-447$.

Haskin, L.A., Helmke, P.A., Paster, T.P., and Allen, R.O., 1971. Rare-earths in meteoritic, terrestrial and lunar matter. In Brunfelt, A.O. and Steinnes, E. (Eds.), Activation analysis in geochemistry and cosmochemistry: NATO Advanced Study Instit., Universitetsforlaget, p. 227-236.

Hubbard, N.J. and Gast, P.W., 1971. Chemical composition and origin of nonmare lunar basalts. In Second Lunar Sci. Conf. Proc: Geochim. Cosmochim. Acta (Suppl. 2), v. 2, p. 999-1020.

Kay, R., Hubbard, N.J., and Gast, P.W., 1970. Chemical characteristics and origin of ocean ridge volcanic rocks: J. Geophys. Res., v. 75, p. 1585-1613.

Masuda, A., Nakamura, N., and Tanaka, T., 1971. Rare earth elements in metagabbros from the mid-Atlantic Ridge and their possible implications for the genesis of alkali olivine basalts as well as the Lizard peridotite: Contrib. Mineral. Petrol., v. 32, p. 295-306.

Montigny, R., Bougault, H., Bottinga, Y., and Allegre, C.J., 1973. Trace element geochemistry and genesis of the Pindos ophiolite suite: Geochim. Cosmochim. Acta, v. 37, p. $2135-2147$. 
Nicholls, G.D. and Islam, M.R., 1971. Geochemical investigations of basalts and associated rocks from the ocean floor and their implications: Phil. Trans. Roy. Soc. London, Ser. A, v. 268, p. 469-486.

Shih, C.Y., 1972. The rare-earth geochemistry of oceanic igneous rocks: Unpublished $\mathrm{Ph} . \mathrm{D}$. Thesis, Columbia University, New York.

Schilling, J.G., 1971. Sea-floor evolution: Rare-earth evidence: Phil. Trans. Roy. Soc. London, Ser. A, v. 268, p. 663-706.

Schnetzler, C.C. and Philpotts, J.A., 1968. Partition coefficients of rare-earth elements and barium between igne- ous matrix material and rock-forming mineral phenocrysts 1. In Ahrens, L.H. (Ed.), Origin and distribution of the elements: Oxford-New York (Pergamon Press), p. 939947.

Schnetzler, C.C. and Philpotts, J.A., 1970. Partition coefficients of rare-earth elements between igneous matrix material and rock-forming mineral phenocrysts II. Geochim. Cosmochim. Acta, v. 34, p. 331-340.

Thayer, T.P., 1969. Peridotite-gabbro complexes as keys to the petrology of mid-oceanic ridges: Geol. Soc. Am. Bull., v. 80 , p. $1515-1522$. 